\title{
Were Modern Capital Structure Theories Valid Before World War I?
}

\author{
Marc Deloof \& Wouter Van Overfelt
}

\author{
UNI VERSI TY OF ANTWERP \\ Faculty of Applied Economics \\ Stadscampus \\ Prinsstraat 13, B.213 \\ BE-2000 Antwerpen \\ Tel. +32 (0)32204032 \\ Fax +32 (0)3220 4799 \\ http://www.ua.ac. be/tew
}




\title{
FACULTY OF APPLIED ECONOMI CS
}

\author{
DEPARTMENT OF ACCOUNTING AND FINANCE \\ Were Modern Capital Structure Theories Valid \\ Before World War I? \\ Marc Deloof \& Wouter Van Overfelt \\ RESEARCH PAPER 2007-024 \\ NOVEMBER 2007
}
University of Antwerp, City Campus, Prinsstraat 13, B-2000 Antwerp, Belgium Research Administration - room B.213
phone: (32) 32204032
fax: (32) 32204799
e-mail: joeri.nys@ua.ac.be

The papers can be also found at our website:

www.ua.ac.be/tew

( research $>$ working papers)

\author{
D/ 2007/ 1169/ 024
}




\title{
Were Modern Capital Structure Theories Valid Before World War I?
}

This Version: 4 September 2007

\author{
Marc Deloof (*) \\ University of Antwerp \\ Wouter Van Overfelt \\ University of Antwerp
}

\begin{abstract}
This study investigates whether capital structure theory can explain debt ratios in an historical environment which was characterized by poor investor protection, booming stock markets and strong banks, and in which corporate income tax did not affect capital structure. Our results, based on a unique, hand-collected sample of 556 firmyear observations for 129 listed companies in pre-World War I Belgium, are remarkably similar to findings for present-day samples. Leverage was positively related to asset tangibility, firm size and firm age, and it was negatively related to profitability and prior stock returns. Bank relationships were associated with lower leverage.
\end{abstract}

JEL Classifications: G32, G21

Keywords: capital structure, corporate income tax, investor protection, bank relationships, universal banks

(*) Corresponding author: Marc Deloof, Department of Accounting and Finance, University of Antwerp, Prinsstraat 13, 2000 Antwerp, Belgium; Email: marc.deloof@ua.ac.be; Tel: +32-3-220 41 69; Fax: +32-3-220 4064

We are grateful to an anonymous referee, Frans Buelens, Jo Danbolt, Marc Jegers, Steven Ongena, Ann Vanstraelen and Ilse Verschueren for helpful comments and suggestions. The paper has also benefited from presentations at the Financial History Workshop in Utrecht (2007), the FMA European meeting in Barcelona (2007) and a seminar at the University of Antwerp. Financial Support from the Flemish Fund for Scientific Research (Grant $n^{\circ}$ G.0013.02) is gratefully acknowledged. Any remaining errors are ours. 


\begin{abstract}
This study investigates whether capital structure theory can explain debt ratios in an historical environment which was characterized by poor investor protection, booming stock markets and strong banks, and in which corporate income tax did not affect capital structure. Our results, based on a unique, hand-collected sample of 556 firmyear observations for 129 listed companies in pre-World War I Belgium, are remarkably similar to findings for present-day samples. Leverage was positively related to asset tangibility, firm size and firm age, and it was negatively related to profitability and prior stock returns. Bank relationships were associated with lower leverage.
\end{abstract}

JEL Classifications: G32, G21

Keywords: capital structure, corporate income tax, investor protection, bank relationships, universal banks 


\section{Introduction}

Modigliani and Miller's famous 1958 article launched an overwhelming amount of research on capital structure. Taxes, costs of financial distress, agency conflicts, governance problems, asymmetric information and interactions between real and financial decisions have been added to their so-called perfect world, in ever so many attempts to explain why capital structure choice does seem to matter. A large number of studies have empirically investigated the determinants of capital structure choice. However, most of these studies are based on data from the U.S. and from other developed economies that have many similarities to the U.S. There are a few exceptions such as Booth et al. (2001), who investigate capital structure choices of firms in 10 developing countries, de Jong et al. (2006), who consider 42 countries around the world including many developing countries, and Huan and Song (2002), who focus on the capital structure of Chinese firms. The results of these studies suggest that debt ratios in developing countries are generally affected in the same way and by the same type of variables that are significant in developed countries. However, Booth et al. and de Jong et al. point out that there are also systematic differences in the way debt ratios are affected by country factors, such the development of capital markets and GDP growth.

In recent years, a number of studies have investigated business and finance decisions in the past to gain insight in present-day corporate finance and corporate governance (e.g. De Long, 1991; Ramirez, 1995; Rajan and Zingales, 2003; Franks, Mayer and Wagner, 2006; Fohlin, 2006). Many of these studies focus on the late $19^{\text {th }}$ and early $20^{\text {th }}$ centuries, because this is widely regarded as the first great era of globalization, and there are close parallels between world finance 100 years ago and today (e.g. Goodhart 
and Delargy, 1998; Bordo and Meissner, 2005). In this paper, we go back to the start of the $20^{\text {th }}$ century to investigate the capital structure of Belgian listed firms. Belgium in this period provides a particularly interesting environment to study capital structure.

First, corporate financing decisions in pre-World War I Belgium were not affected by taxes. In the period considered, firms paid only a $2 \%$ "patent tax" on all revenues to the financiers: capital gains, dividends and interests (Belgian Law of 22 January 1849, Art. 3 and Belgian Law of 5 July 1871, Art. 12). Moreover, there were no personal taxes on dividends, which were introduced only in 1920 (De Visschere, 1935; Janssens et al., 1990).

Second, by modern standards institutions were weak, investors were poorly protected, and they faced severe information problems. Théate (1905), a contemporary Belgian law scholar, argued that investors in Belgium were badly protected as compared to investors in other European countries such as Britain, France and Germany. Recent company law reforms had reduced the opportunities for investor expropriation in these countries, and according to Théate such a company law reform was also badly needed in Belgium. This reform would eventually take place in 1913. Notwithstanding weak investor protection, Belgium combined a very active stock market with a strongly developed banking sector. Rajan and Zingales (2003) find that in 1913, Belgium had the second largest fraction of gross fixed capital formation raised through equity and the largest number of publicly traded domestic firms per capita. Moreover, the ratio of stock market capitalization over GDP in Belgium (0.99) was similar to the ratio in the U.K. (1.09) and much higher than in the United States (0.39), Germany (0.44) or Japan (0.49). At the same time, the ratio of commercial and savings deposits over GDP 
indicates that the banking sector was more developed in Belgium (0.68) than in Germany (0.53), the U.S. (0.33), Japan (0.13) or the U.K. (0.10).

For a unique, hand-collected sample of 556 firm-year observations for 129 listed companies in pre-World War I Belgium, we investigate to what extent factors suggested by capital structure theories were correlated with leverage. We consider both debt scaled by the book value of total assets, and debt scaled by the market value of equity plus the book value of total debt. Moreover, the available data allow us to distinguish between bonds and other debt. In an environment which was characterized by weak investor protection and a lack of corporate taxes, we expect asymmetric information and agency problems to have been important drivers of debt policy. We do not expect that firms targeted an optimal capital structure as suggested by the Static Trade-Off Model, because there were no tax advantages of debt which could be traded off against the financial distress costs of debt. This is confirmed by our results. We find that the factors correlated with leverage are remarkably similar to those for present-day samples. Leverage was positively related to asset tangibility, firm size and firm age, and it was negatively related to profitability. We also find that debt ratios based on market values were negatively correlated with prior stock returns. This suggests that firms did little to counteract stock price changes (Welch, 2004).

In the period considered in this study, many Belgian firms had bank directors on their board. We find that bankers on the board were associated with lower leverage, which is consistent with the hypothesis that a bank director made it easier for firms to issue new equity. It contradicts the hypothesis that firms had bankers on their board to obtain more debt, either through monitoring by lending bankers, or through non-affiliated bankers providing bank debt market expertise. 
The remainder of the paper is structured as follows. Section 2 discusses capital structure theories, factors that might be correlated with leverage, and the role bank relationships. Section 3 discusses the construction of the sample and the variables. The empirical results are presented in section 4. Section 5 concludes.

\section{Literature}

\subsection{Capital structure theories}

The principal theoretical models of capital structure center on the idea that firms have information that investors do not have, and that the interests of managers, equityholders and debtholders may not coincide. The two dominant models are the Static Trade-Off model and the Pecking Order model. In the Static Trade-off model, capital structure moves towards and optimum leverage which is determined by balancing the corporate tax savings advantage of debt and the costs of financial distress. This idea has been developed in many papers, including Brennan \& Schwartz (1978), DeAngelo and Masulis (1980) and Bradley, Jarrell and Kim (1984). However,

it has been questioned by many others, including Miller (1977) and Graham (1990), who argue that the Static Trade-off model implies that many firms should be more highly levered than they really are, as the tax savings of debt seem large while the costs of financial distress seem minor.

A related literature focuses on the role of agency conflicts between managers, shareholders and debt holders. Managers are agents of the shareholders, but the interests of managers and shareholders may be in conflict. Managers may pursue personal interests at the expense of shareholders by overinvesting free cash flow (the excess of cash earnings over profitable investments) in perquisites and bad projects 
(the overinvestment problem). According to authors such as Jensen (1986) and Stulz (1990), debt may be useful to control for such misbehavior since debt must be repaid to avoid bankruptcy. Bankruptcy is costly for managers since they may lose their job.

There are also agency conflicts between debt-holders and shareholders. Myers (1977) shows that a highly debt-financed firm might forego good investment opportunities because debt holders can share in profitable future investment returns, thereby extracting some wealth of the shareholders. This wealth extraction may cause the shareholders to turn down profitable investment projects (the underinvestment problem). Moreover, equity can be seen as a call option on the firm, and call values increase with the volatility of the underlying asset. This creates incentives for the shareholders to shift the firm's investments in high risk projects, at the expense of the debt-holders (the risk-shifting problem). Shareholders of highly indebted firms may even select investment projects with a negative present value, because the increase in risk leads to a wealth transfer from debt-holders to shareholders that exceeds the net present value of the project.

Myers and Majluf (1984) provided a theoretical foundation for the proposition of Donaldson (1961) that there is a financing hierarchy, where firms prefer internal finance, and if external finance is required firms issue the safest security first. In the Pecking Order model of Myers and Majluf, raising external finance is costly because insiders have more information about the firm's prospects than outside investors, and outside investors know this. From the perspective of outside investors, equity is riskier than debt. They will rationally demand a higher risk premium for equity than for debt. From the point of view of the insiders, debt is therefore a better source of funds than equity is, and internal funding is even better. Debt financing will only be used when 
there is an inadequate amount of internal funding available, and equity will only be used as a last resort. As a consequence, there is no optimal leverage. Observed leverage is simply the sum of past financing events.

A number of papers have tried to explain the observation that firms tend to issue equity when their stock prices are high. Baker and Wurgler (2002) argue that firms issue equity when it is overvalued by irrational investors. Capital structure is the cumulative outcome of past attempts to time the equity market. Lucas and McDonald (1990) and Korajczyk, Lucas and McDonald (1991) on the other hand posit that adverse selection costs are time-varying, as are stock prices, and firms will issue equity when stock prices are high if a high stock price coincides with low adverse selection. According to Dittmar and Thakor (2007), managers will issue equity to finance a project when there is agreement among managers and investors that the project is a good project. In their view, the link between stock prices and equity issues emerges because a higher stock price is evidence of market agreement.

Welch (2004) shows that the market-based debt-equity ratios of U.S. companies vary inversely with fluctuations in their own stock prices, because these companies do little to counteract the influence of stock price changes on their capital structure. The stock price effects are often large and last a long time, at least several years.

\subsection{Factors correlated with leverage}

Capital structure theories suggest a number of factors that may be correlated with leverage. In this paper, we focus on factors that are commonly used in the empirical literature on capital structure: the market-to-book ratio, asset tangibility, profitability, firm size and firm age (see e.g. Titman and Wessels, 1988; Rajan and Zingales, 1995; 
Booth et al., 2001; Fama and French, 2002, Frank and Goyal, 2003; de Jong et al., 2006). We also consider the firm's prior stock return (Welch, 2004).

The market-to-book-ratio is usually thought of as a proxy for investment opportunities $^{1}$. The agency costs of debt suggest a negative relationship between investment opportunities and debt levels. As shown by Myers (1977), highly levered firms are more likely to pass up profitable investment opportunities. Moreover, the expected costs of financial distress are higher for firms with good investment opportunities. Therefore, it is expected that firms with good investment opportunities will use a greater amount of equity finance.

As Rajan and Zingales (1995) note, there might still be other reasons why the marketto-book ratio is negatively correlated with leverage. A higher leverage may increase the risk of financial distress, which could reduce the market value of shares. The tendency for firms to issue stock when their stock price is high relative to book value, may also lead to a negative correlation between the market-to-book ratio and the ratio of debt to the book value of assets.

Asset tangibility is commonly assumed to be positively correlated with leverage. Tangible assets are easy to collateralize and thus they reduce the agency costs of debt. If assets cannot be collateralized, creditors may require more favorable terms, which may lead firms to use equity rather than debt financing ${ }^{2}$. Moreover, it can be expected that a high proportion of tangible assets reduces the risk of financial distress.

\footnotetext{
${ }^{1} \mathrm{R} \& \mathrm{D}$ expenses is another measure of investment opportunities commonly used in the empirical literature. However, our data do not allow us to measure R\&D expenses.

${ }^{2}$ In the period considered in this study, secured creditors in Belgium could repossess collateral and they had priority over other creditors (Musacchio, 2006).
} 
However, Titman and Wessels (1988) point out that the tendency of managers to pursue personal interests at the expense of shareholders might produce a negative relation between tangible assets and debt levels. As noted by e.g. Jensen (1986), high debt levels control for such misbehavior since debt must be repaid to avoid bankruptcy. The agency costs of managerial discretion may be higher for firms with assets that are less collateralizable since monitoring the cash outlays of such firms is probably more difficult. For this reason, firms with less tangible assets may choose high debt levels to limit managerial discretion.

The Pecking Order Theory predicts that firms with high profitability will need less external financing and will therefore have lower debt ratios $^{3}$. On the other hand, if firms use debt as a means of reducing tax payments as suggested by the trade-off theory, firms with higher profits should have higher debt ratios. Higher profits allow the firm more corporate tax deductions. However, this argument does not apply to our sample, as there was basically no corporate income tax in the period considered. Rajan and Zingales (1995) point to another rationale for a positive relationship between profitability and leverage: if the market of corporate control is effective, it may force firms to commit to paying out cash by levering up, which would also lead to a positive relationship between profitability and leverage.

Firm size may be correlated with leverage for a number of reasons. Size is often considered as a proxy for the probability of default: larger firms tend to be more diversified and to have less volatile assets, and are therefore less likely to fail and to be

\footnotetext{
${ }^{3}$ Strebulaev (2006) also argues that in a dynamic economy with frictions, cross-sectional tests may reveal a negative relation between profitability and leverage if firms optimally adjust their leverage only infrequently.
} 
liquidated ${ }^{4}$. From this point of view a positive relation between size and leverage is to be expected. However, size may also be an inverse proxy for informational asymmetries between insiders in a firm and the capital markets. Larger firms should be more capable of issuing equity, and should therefore have lower debt ratios. An alternative proxy for the information outside investors have is firm age. Older firms are better known to outside investors and should therefore find it easier to issue informationally sensitive equity.

The relationship between size and leverage may also be affected by the transaction costs of raising external funds. Kurshev and Strebulaev (2005) demonstrate that in a dynamic capital structure model with fixed costs of raising external funds, crosssectional tests may reveal a positive relation between size and leverage if firms adjust their leverage only infrequently.

Welch (2004) argues that prior stock returns are the primary determinant of marketbased debt ratios, as firms do not counteract the influence of stock price changes on their capital structures. The other proxy variables used in the literature fail to explain much of capital structure dynamics when stock returns are taken into account. According to Welch, many of these proxies only seem to help explain capital structure dynamics because they correlate with omitted stock return dynamics.

\subsection{The role of bank relationships}

In the late $19^{\text {th }}$ and early $20^{\text {th }}$ century, banks in industrializing countries generally played a dominant role in corporate finance (e.g. Cameron, 1967; Carosso, 1970; Rajan

\footnotetext{
${ }^{4}$ We could also use time-series data to estimate volatility, but estimates of volatility based on 5 years of data are likely to be a very noisy measure. Moreover, it would limit our sample to survivors with a sufficient number of data.
} 
and Zingales, 2003; Fohlin, 2006). This was also the case in Belgium, where by 1913 the banking sector was more developed than in the U.S., the U.K., Germany and Japan (Rajan and Zingales, 2003). The most prominent of these banks were universal banks, which offered a wide range of services to firms: they took equity stakes, provided loans, assisted firms in the issuance of securities and were often involved in the management of affiliated firms (e.g. Kurgan-Van Hentenryk, 1991). According to Durviaux (1947), in the early $20^{\text {th }}$ century universal banks contributed most of the money for the financing of new securities issued by Belgian firms, either by investing in securities themselves, or by selling securities to the public. Van Overfelt et al. (2006) find that in the period considered in this study many Belgian firms indeed had bank directors on their board. Moreover, their results suggest that these bank relationships had a positive impact on firm performance. This raises the question how bank relationships affected capital structure.

\section{(a) Monitoring}

First, it could be argued that bank relationships facilitated the provision of bank loans. Bank loans are typically the most closely monitored mode of finance. Delegated monitoring by a financial intermediary has lower monitoring costs than monitoring by a group of individual borrowers, and it avoids the free rider problem (Diamond, 1984). Such monitoring is thought to alleviate risk-shifting behaviour as well as over- and underinvestment (Jensen and Meckling, 1976; Myers, 1977; Stulz, 1990). The provision of several services by universal banks encourages long-term relationships with borrowers, which lead to a better exchange of information between bank and borrower, more flexible contracting, intertemporal smoothing of contract terms, and better monitoring of activities and outcomes by the bank (Boot, 2000). Moreover, if the 
bank is not only a debtholder but also a shareholder of the firm, agency conflicts between debtholders and shareholders are likely to be less important. Firms affiliated with a (universal) bank should therefore find it easier to obtain bank loans. This could result in higher debt ratios.

Rajan (1992) also points out that the proprietary information about borrowers that banks obtain as part of their relationships may give them an information monopoly. Banks may abuse this information monopoly by charging high interest rates, and they may even force affiliated firms to overborrow in order to earn more interest.

These arguments imply that the presence of bankers whose banks are lending to the firm is positively related to firm debt. However, Booth and Deli (2001) find for a sample of U.S. firms that it is the presence of commercial bankers who have no relationship with the firm other than as a director which is positively related to firm debt. The explanation they offer is that non-affiliated bankers provide bank debt market expertise.

\section{(b) Certification}

It has been argued that a primary role of banks in the late $19^{\text {th }}$ and early $20^{\text {th }}$ centuries was to remove barriers for firms to capital markets (e.g. Carosso, 1970; De Long, 1991; Ramirez, 1995; Baskin and Miranti, 1997; Franks, Mayer and Wagner, 2006). Board positions may have provided signals of credit worthiness to capital markets. A bank with access to more timely information and with incentives to produce more durable information can better certify offer prices in securities issues. According to Carosso (1970) and Baskin and Miranti (1997), in the U.S. during the second half of the $19^{\text {th }}$ century specialized railroad underwriters - banks with reputations for honesty and competency - mitigated the uncertainties associated with railroad finance. Wealthy 
investors in both the U.S. and Europe relied on the professional counsel of J.P. Morgan \& Company and Kuhn-Loeb \& Company in deciding where to commit their capital. Ramirez (1995) finds that firms affiliated with J. P. Morgan in the early $20^{\text {th }}$ century were indeed less liquidity constrained, and DeLong (2001) shows that the presence of directors affiliated with J.P. Morgan was associated with higher firm value. Jagannathan and Krishnamurthy (2004) find that even today, U.S. firms with investment banker directors are more likely to pay dividends, to have a credit rating and to issue commercial paper, and they pay out a larger fraction of their earnings. Moreover, they are able to raise larger amounts of external equity capital, with smaller underpricing and lower underwriting fees. The finding of Deloof et al. (2006) that in the period considered in this study, Belgian firms with a banker on their board paid higher and more stable dividends than stand-alone firms is consistent with the "certification" role of bank directors.

From this perspective, a negative relation between leverage and bank relationships could be expected. The presence of bankers on the board makes it easier for the firm to issue securities to investors. These securities might be bonds as well as stocks, but the "reputation" effect of banks is likely to be stronger for stocks. From the point of view of investors stocks are riskier than bonds, and the advantage of a bank endorsing the issue's "investment quality" will be greater.

\section{(c) Conflicts of interest}

The different payoff structures associated with debt and equity lead to divergent interests in how the shareholders and the creditors prefer the firm to be run. Creditors prefer that the firm maximizes the probability of debt repayment rather than maximize the expected returns to shareholders. It could therefore be argued that lending bankers 
on the board exercised downward pressure on the debt ratio in order to protect the interests of the lending bank (e.g. Kroszner and Strahan, 2001; Byrd and Mizruchi, 2005). However, the results of Deloof et al. (2006), who investigate the dividend policy of Belgian firms in the period considered, are inconsistent with this hypothesis. They find that firms with a bank director paid higher dividends, and higher dividends are against the interests of the lending $\operatorname{bank}(\mathrm{s})^{5}$.

\section{Sample and Variables}

\subsection{Sample}

We constructed a sample of listed Belgian firms during the period 1905-1909 in four major industries: coal-mining, trams, railways and textile. These were the four largest industries in terms of (i) the number of companies in the industry and (ii) the number of companies with a bank director. To be included in the sample, we require that a firm had a listing on the Brussels Stock Exchange for at least one year. The firms listing or delisting in a particular year are therefore not considered in the year of listing or delisting. As noted in the introduction, the 1905-1909 period was characterized by unprecedented globalization, increasing international competition and extended financial development, and Belgium at that time had a particularly interesting institutional environment.

Stock market data were collected from a database constructed at the University of Antwerp by the "StudieCentrum voor Onderneming en Beurs" (SCOB). The primary source of this database is the archive of the Brussels Stock Exchange. The data were

\footnotetext{
5 They also find that the bank held an equity stake in a substantial number of firms, which would mitigate the debt/equity agency conflict.
} 
hand-collected and double checked from various sources including the official quotation list and firms' correspondence with the exchange. The database includes all listed firms, contains information on share prices, dividends, the number of stocks outstanding and goes back as far as 1832 (see http://www.scob.be). In addition, a sector classification code, based on the primary activity of the firm, and a geographical code which identifies the location of the firm's activity was assigned to each firm. We restrict our sample to Belgian firms with main activities in Belgium (as defined by SCOB).

We also collected financial statement data. The financial statement data were handcollected data from the appendices to the Official Gazette ("Annexes au Moniteur Belge: Recueil Spécial des Actes des Sociétés"). This is the most reliable source of Belgian financial statement data for that period. All firms constituted under Belgian corporate law were legally required to publish their balance sheets and income statements in the Official Gazette no later than two weeks after the approval by the general meeting (Théate, 1905). At least one month before the annual meeting, the executive board of the firm had to deliver a (non-public) report ("inventaire") to the supervisory board (“commissaires") for approval. After approval, an annual report containing the balance sheet and the income statement had to be deposited at the head office of the firm and had to be sent to all nominal shareholders at least two weeks before the general meeting. The general meeting had to approve the annual report. For a number of firms we were able to obtain the annual report presented at the general meeting, and we found that the balance sheet and income statement presented in the annual report were the same as the ones reported in the appendices of the Official Gazette. 
Since the discretionary power of management to design the financial statement was high, there is substantial heterogeneity in the structure of the financial statements and we had to reformat the financial statements in a uniform structure. Fortunately, the law provided guidelines about the depreciation of assets and the distribution of profits (Resteau, 1913a and 1913b) and we are able to check practitioners' guides to get a better understanding of the accounting principles at the turn of the century (François, 1902 and 1907).

Insert Table 1 about here

After removing observations with missing values for the variables considered in the empirical analysis, one observation for which the total debt ratio was greater than one, and one observation for which asset tangibility was greater than one, our sample consists of 556 firm-year observations for 129 different firms. Table 1 reports the number of firm-year observations for each industry: a majority of the firms in our sample are coal-mining firms ${ }^{6}$.

\subsection{Variables}

Fama and French (2002) note that there is some ambiguity about the extent to which predictions of the main capital structure theories apply to debt ratios based on market values, or to debt ratios based on book values. Because of this ambiguity, we always present empirical results for debt scaled by the book value of total assets, and debt scaled by the market value of equity plus the book value of total debt. Firms can obtain

\footnotetext{
${ }^{6}$ An overview of all the firms included in the sample, with the average year-end market value of equity and the industry to which they belong can be found in the appendix.
} 
debt in a variety of forms, from different sources. The financial statements of the firms considered in this study allow us to distinguish between two forms of debt: “obligations" or bonds, and "créditeurs", which is all other debt. "créditeurs" could be bank debt but also trade liabilities. We therefore consider six different debt ratios: total debt, bonds and other debt are each scaled by the book value of total assets and by the market value of equity plus the book value of total debt. Finally, we also consider a Bonds dummy, which equals one if the firm has bonds outstanding, and zero otherwise.

As for the explanatory variables, the market-to-book ratio of equity is market value of equity (aggregated over all categories of stock) divided by the book value of equity at the beginning of the fiscal year. Asset tangibility is defined as the ratio of fixed assets over total assets at the beginning of the fiscal year. Profitability is operating profit plus depreciation over the fiscal year, divided by the book value of total assets at the beginning of the fiscal year. $\operatorname{Ln}($ size) is the natural logarithm of total assets at the beginning of the fiscal year; and $\ln ($ age $)$ is the natural logarithm of difference between the current year and the year the firm transformed to a limited liability company. Prior stock return is the stock return net of dividends over the previous fiscal year ${ }^{7}$.

Insert Table 2 about here

Table 2 presents descriptive statistics. The debt ratio of the firms in our sample was generally low. The average total debt ratio based on market values was $19.8 \%$, of

\footnotetext{
${ }^{7}$ Some firms had more than one type of stock listed on the stock exchange. In that case we use the weighted average of stock returns.
} 
which $10.3 \%$ were bonds and $9.5 \%$ was other debt. However, there are large differences across firms. The median total debt ratio is only $10.7 \%$. While bonds seem to have been an important financing tool for some firms in the sample, the median firm did not issue any bonds. Debt ratios based on book values depict a similar picture, with the average total debt ratio being $26.9 \%$ (median is $19.9 \%$ ).

Insert Table 3 about here

There might be substantial heterogeneity of our sample with respect to the market power of the four industries. Two industries - trams and railways - were natural monopolies, whose earning streams might have been much more assured than earnings of firms operating in coal-mining and textile. This could affect capital structure ${ }^{8}$. To investigate whether the average and median debt variables in Table 2 mask significant differences in capital structure due to competitive risk, we calculated mean and median values by industry for the debt variables and for the explanatory variables. Table 3 shows that debt ratios tended to be similar in the tram, railways and textile industries. However, coal-mining firms generally had much less debt than firms in the other industries. They made very little use of bonds: the average bonds (market) ratio for coal mining firms is only $3.3 \%$. This ratio is much higher for the other industries in the sample. The low debt ratio for coal-mining firms may have been a consequence of the relatively high profitability of these firms. The average profitability in the coal-mining industry was $16.9 \%$, while it was $7.7 \%$ in the trams industry, $4.2 \%$ in the railways

\footnotetext{
${ }^{8}$ We thank the referee for pointing this out. These differences in competitive structure may have been offset somewhat if the mining and textile industries in Belgium were organized as cartels. However, we have no information that this was the case in the period considered in this study.
} 
industry, and $10.8 \%$ in the textile industry. To capture industry-specific debt policies in the regression analysis, we will include industry dummies for the trams industry, the railways industry and the coal-mining industry as explanatory variables.

\subsection{Bank relationships}

Regarding the impact of bank relationships, we assume a bank relationship if the firm has a bank director on its board: a relationship at the board level represents a continuous interaction and information exchange between the firm and the bank ${ }^{9}$. As in Germany, the boards of Belgian firms had a dual structure, consisting of an executive board ("administrateurs") and a supervisory board ("commissaires"). The executive board members acted on behalf of and for the account of the firm, they were appointed by the articles of incorporation or by the general meeting of shareholders, and their responsibilities were limited by the firm's articles of incorporation. Supervisory board members were charged with the supervision of the executive board members and they had to approve the firm's annual accounts.

We collected data on the board of directors from the "Recueil Financier", a financial annual containing a variety of firm-specific information, including the members of the board as well as their mandate (executive board or supervisory board) and sometimes their domicile. To check the accuracy of the "Recueil Financier", we compared the information in the "Receuil Financier" with the entries in the appendices of the Official

\footnotetext{
${ }^{9}$ As an alternative measure of bank affiliation, we also considered a dummy variable which equals one if a universal bank held an equity stake in the firm. However, this measure was never significant in any of the regressions (results available from the authors upon request).
} 
Gazette for a sub-sample of firms but we found no differences. Bank directors are based on the boards of $1905^{10}$.

We consider bank relationships with six different banks: (i) the Société Générale; (ii) the Crédit Général Liégeois; (iii) the Banque d'Outremer; (iv) the Banque Liégeoise; (v) the Banque de Bruxelles and (vi) the Banque Internationale de Bruxelles. These were the most important listed universal banks both in terms of total assets and the value of the industrial portfolio (Durviaux, 1947; see also Van Overfelt et al., 2006).

As a consequence of the two-tier board structure, four different types of bank relationships can be considered: bank executive directors on the firm executive board; bank executive directors on the firm supervisory board; bank supervisory directors on the firm executive board; and bank supervisory directors on the firm supervisory board. While executive directors held a significant number of directorships in other firms, their supervisory peers rarely held directorships in other firms. We therefore assume a bank relationship if an executive director of the bank is on the executive board of the firm.

We cannot rule out the possibility that some of these directors were in fact industrialists sitting on the board of a bank, and not bankers on the board of industrial firms. However, anecdotal evidence suggests that these directors generally were representing the interests of the bank. For example, Edouard Despret, who died in October 1906, held board positions in 19 different firms at the time of his death. He

\footnotetext{
${ }^{10}$ For some companies that went public after 1905, we also used the 1905 board if it was available in the Recueil Financier. If it was not available, we used the board from the year the listing started. Bank relationships were very stable anyway. Van Overfelt et al. (2006) find for the same sample that most firms with a bank director in 1905 already had a bank director in 1895, and most firms without a bank director in 1905 did not have a bank director in 1895 .
} 
was the vice-president of the Société Générale, which was by far the largest bank in Belgium. In November 1906, he was succeeded on the board of the Société Générale by Jean Jadot. Before becoming a director of the Société Générale, Jean Jadot held no board positions at all. Three years later, he was a director of 13 different firms. In most of these firms, Edouard Despret had been a director when he died ${ }^{11}$. All the firms in which Edouard Despret held positions before his death still had one or two Société Générale Directors in 1909.

Insert Table 4 about here

Table 4 depicts the number of bank directors and the number of related banks for the 126 firms in our sample. 47 firms had at least one bank director on their board. The highest number of bank directors was four (six firms), but most firms either had one bank director (26 firms) or two bank directors (seven firms). 35 firms were related to one bank, 10 firms were related to two banks and two firms were related to three different banks.

\footnotetext{
${ }^{11}$ Sources: the 1906 annual report of the Société Générale and the 1906 and 1910 editions of the Receuil Financier.
} 


\section{Empirical Results}

Table 5 presents the results of regressions which include market-to-book ratio, asset tangibility, profitability, $\ln ($ size $), \ln ($ age $)$, the bank director dummy and industry dummies as independent variables. All regressions are estimated assuming random effects. We use clustered standard errors to asses the significance of the estimated coefficients. Standard errors clustered by firm account for the fact that standard errors of regression coefficients are downward biased if residuals are correlated across time for a given firm. When both a firm and a time effect are present in the data, the time effect can be addressed by including time dummies and then estimate standard errors clustered on the other dimension (Petersen, 2006).

In regression 1, the dependent variable is total debt scaled the market value of equity plus the book value of total debt, and in regression 2 it is total debt scaled by the book value of total assets. The results for asset tangibility, size and age and profitability are generally consistent with capital structure theories.

We find that total debt was significantly positively related to asset tangibility, confirming the hypothesis that tangible assets reduce the agency costs of debt because they can be used as collateral. Furthermore, total debt was significantly negatively related to profitability. This result is consistent with most empirical studies on capital structure, and it confirms the Pecking Order theory, according to which a firm first uses retained earnings to finance new investments before raising external finance, because of asymmetric information costs. 
Empirical capital structure studies have found contradictory results on size and age. For example, the multi-country studies of Rajan and Zingales (1995), Booth et al. (2001), and de Jong et al. (2006) all find both positive and negative relationships. In our sample, larger and older firms had more debt. This is consistent with the hypothesis that larger and older firms could afford higher levels of leverage because they tended to be more diversified and to have more stable cash flows.

As for the market-to-book ratio, we find that the market based total debt ratio was not significantly related to the market-to-book ratio, while the book based total debt ratio was significantly positively related to the market-to-book ratio. As discussed in section 2, capital structure theory suggests a negative relationship between leverage and the market-to-book ratio. Most studies indeed find a significant negative relationship (see e.g. Rajan and Zingales, 1995), but Booth et al. (2001) and de Jong et al. (2006) find a significant positive relationship in some developing countries. A more negative relationship for the market based debt ratio than for the book based debt ratio could be due to spurious correlation introduced by having market values in the numerator of the market-to-book ratio and the denominator of the market total debt ratio. However, it remains unclear why there was a positive relationship between the market-to-book ratio and the book total debt ratio. A possible explanation could be that firms of which the stock was highly valued found it easier to issue debt.

Interestingly, the bank director coefficient is negative in both regression 1 and regression 2, and it is significant at the 5\% level in regression 1: a bank director on the board reduced the market total debt ratio by $6.7 \%$. This result contradicts the hypothesis that firms had bankers on their board to obtain more debt, either through monitoring by lending bankers, or through the provision of bank debt market expertise 
by non-affiliated bankers (e.g. Booth and Deli, 1999; Byrd and Mizruchi, 2005). It is consistent with the hypothesis that a banker on the board made it easier for firms to issue new equity, and with the hypothesis that lending bankers on the board exercised downward pressure on the debt ratio in order to protect the interests of the bank. However, as noted in section 2.3., the results of Deloof et al. (2006) on dividend policy of Belgian firms in the period considered are inconsistent with the latter hypothesis.

Finally, consistent with the results in Table 3 we find a significantly negative coefficient for the coal-mining dummy: coal-mining firms had less debt than tram, railways and textile firms ${ }^{12}$.

To gain further insight in the capital structure of the firms in our sample, we investigate bonds and other debt separately. Dependent variables are the likelihood of bonds outstanding (regression 3), the market based bonds ratio (regression 4), the book based bonds ratio (regression 5), the market based other debt ratio (regression 6), and the book based other debt ratio (regression 7). Regression 3 is estimated with the Random Effects Probit Model.

In all these regressions the market-to-book coefficient is insignificant, except in regression 7, where the positive coefficient is significant at the $10 \%$ level. Asset tangibility on the other hand was significantly and positively related to (the likelihood of) bonds (regressions 3, 4, 5), while it was negatively related to other debt (regressions 6,7). This implies that firms with more fixed assets had more bonds but less other debt, which is consistent with the traditional matching argument that long-

\footnotetext{
${ }^{12}$ We estimated all the regressions in the paper separately for the coal-mining industry and for the other three industries in our sample. The results are generally consistent with those reported in the paper, with some differences: $\ln$ (size) and the bank director dummy tend to be insignificant for the sample of coal mining firms, while they are significant for the other industries.
} 
term assets should be financed with long-term liabilities (assuming that the average maturity of other debt was shorter than the average maturity of bonds). Firms with fewer tangible assets turned to other debt instead of bonds.

Not surprisingly, profitability was negatively related to bonds and to other debt, although the profitability coefficient is not significant in regression 3 (likelihood of bonds) and in regression 4 (market based bonds ratio).

Size was positively related to (the likelihood of) bonds, but not to other debt. Age was also significantly and positively related to bonds. These results suggest that in preWorld War 1 Belgium, which was an environment characterized by high asymmetric information, older and larger firms found it easier to issue bonds.

We also find that a banker on the board was significantly negatively related to the market based bonds ratio (regression 4), but it was not related to other debt. Assuming that universal banks gained board positions as a result of equity underwriting, this suggests that new equity may have been an alternative for bonds, but not for other debt.

As for the industry-dummies, coal-mining firms had significantly less bonds and less other debt than textile firms. Trams and railways firms had less other debt than textile firms.

Insert Table 6 about here

Table 4 revealed a substantial heterogeneity regarding the number of bank directors and the number of related banks. We therefore also estimated regressions which include the number of bank directors and the number of related banks. However, the 
results (reported in Table 6) suggest that neither the number of bank directors (regressions 8 and 9) nor the number of related banks (regression 10 and 11) was significantly related to total $\mathrm{debt}^{13}$.

Insert Table 7 about here

We also included the stock return in the previous year as an additional explanatory variable in the model. Debt ratios may have varied with fluctuations in stock prices, if firms did little to counteract the influence of stock price changes on their capital structures (cf. Welch, 2004). As there were no tax advantages to debt in the period considered, and the debt ratios of the firms in our sample were relatively low, it indeed seems unlikely that firms tried to rebalance their capital structure in response to stock price fluctuations. This is confirmed by the results in Table 7. The stock return over the previous fiscal year was significantly and negatively related to the market based total debt ratio (regression 12), while it was not related to the book based total debt ratio (regression 13). When we consider bonds and other debt separately, the effect is almost equal for the market based bonds ratio (regression 14) and the market based other debt ratio (regression 15).

The dependent variable in our regressions varies between 0 and 1 , which may affect our results. As a robustness check, we therefore also estimated all regressions reported in the paper with the logistic transformation of the debt ratio, that is, log [debt ratio /

\footnotetext{
${ }^{13}$ When we consider bonds and other debt separately, the number of bank directors and the number of related banks are also always insignificant (results not reported, available from the authors upon request).
} 
(1-debt ratio)] as dependent variable. The results of these regressions (not reported) are generally consistent with those reported in the paper.

It is interesting to compare our results to those of Fohlin (2006). Her book on the development on universal banks, securities markets and corporate finance in Germany in the two decades before World War I includes a study on the capital structure of German firms. To the best of our knowledge, it is the only other study which investigates capital structure in an historical environment such as the one considered in our study. Consistent with our findings, her results suggest that leverage was positively related to tangibility and size, and it was negatively related to profitability. As we do, she finds that bank affiliations reduced leverage. One difference between her results and ours is the effect of age: she finds that older firms had lower debt ratios. However, we have to be careful when interpreting the age variable. Both in the study of Fohlin and in ours, age is defined as the number of years since incorporation, which could be very different from the actual age of the company since it was founded as a private firm.

\section{Conclusion}

This study investigates the factors correlated with leverage in an historical environment which was characterized by poor investor protection, booming stock markets and strong banks, and in which corporate income tax did not affect capital structure. The results on factors correlated with debt confirm to a large extent those for present-day samples. Leverage was positively related to asset tangibility, firm size and firm age, and it was negatively related to profitability. These findings are consistent with theories stressing the role of asymmetric information and agency conflicts as determinants of capital structure. 
We also find that bankers on the board were associated with lower leverage, which confirms the hypothesis that a bank director made it easier for firms to issue new equity. It contradicts the hypothesis that bank affiliations allowed firms to obtain more debt, either because of monitoring by lending bankers, or because non-affiliated bankers provided bank debt market expertise.

\section{References}

Baker, M. and J. Wurgler (2002), 'Market Timing and Capital Structure', Journal of Finance, Vol. 57, No. 1, pp. 1-32.

Baskin, J.B. and P.J. Miranti, Jr. (1997), A History of Corporate Finance (Cambridge: Cambridge University Press).

Boot, A. (2000), 'Relationship Banking: What Do We Know?', Journal of Financial Intermediation, Vol. 9, pp. 7-25.

Booth, J. and D.N. Deli (1999), 'On Executives of Financial Institutions as Outside Directors', Journal of Corporate Finance, Vol. 5, pp. 227-250.

Booth, L., V. Aivazian, A. Demirguc-Kunt, and V. Maksimovic (2001), 'Capital Structures in Developing Countries', Journal of Finance, Vol. 56, No. 1, pp. 87-130.

Bordo, Michael D. and Christopher M. Meissner (2005), 'The Role of Foreign Currency Debt in Financial Crises: 1880-1913 vs. 1972-1997', Working Paper (National Bureau of Economic Research).

Bradley, M., G.A. Jarrell and E.H. Kim (1984), 'On the Existence of Optimal Capital Structure: Theory and Evidence', Journal of Finance, Vol. 39, pp. 857-878. 
Brennan, M..J. and E.S. Schwartz (1978), 'Corporate Income Taxes, Valuation, and the Problem of Optimal Capital Structure', Journal of Business, Vol. 51, pp. 103-114.

Byrd, D.T. and M.S. Mizruchi (2005), 'Bankers on the board and the debt ratio of firms', Journal of Corporate Finance, Vol. 11, pp. 129-173.

Cameron, R. E. (1967), Banking in the Early Stages of Industrialization: A Study in Comparative Economic History (Oxford: Oxford University Press).

Carosso V.P. (1970), Investment Banking in America : A History (Cambridge: Harvard University Press).

DeAngelo, H. and R.W. Masulis (1980), 'Optimal Capital Structure under Corporate and Personal Taxation', Journal of Financial Economics, Vol. 8, pp. 3-29.

De Jong, A., R. Kabir and T.T. Nguyen (2006), 'Capital Structure around the World: The Roles of Firm- and Country-Specific Determinants', Working Paper (RSM Erasmus University).

De Long, Bradford. J. (1991), 'Did J. P. Morgan's Men Add Value? An Economist's Perspective on Financial Capitalism.', in P. Temin (ed.), Inside Business Entreprise: Historical Perspectives on the Use of Information (Chicago: University of Chicago Press).

De Visschere, F.E. (1935), Het Belgische Belastingswezen en zijn Grondslagen. (Brussels: Standaard-Boekhandel)

Deloof, M., A. Roggeman and W. Van Overfelt (2006), 'Who's Afraid of Universal Banks? Universal Bank Affiliations and Corporate Dividend Policy in Pre-World War I Belgium', Working Paper (University of Antwerp). 
Diamond, D.W. (1984), 'Financial Intermediation and Delegated Monitoring', Review of Economic Studies, Vol. 51, No. 3, pp. 393-414.

Dittmar, A. and A. Thakor (2007), 'Why Do Firms Issue Equity?', Journal of Finance, Forthcoming.

Donaldson, G. (1961), Corporate Debt Capacity (Boston: Harvard University Press).

Durviaux, R. (1947), La Banque Mixte: Origine et Soutien de l'Expansion Economique de la Belgique (Brussels : Etablissements Emile Bruylant).

Fama, E.F. and K.R. French (2002), 'Testing Trade-Off and Pecking Order Predictions About dividends and Debt', Review of Financial Studies, Vol. 15, No. 1, pp. 1-33.

Fohlin, C. (2006), Finance Capitalism and Germany's Rise to Industrial Power: Corporate Finance, Governance, and Performance from the 1840s to the Present (Cambridge: Cambridge University Press).

François, A. (1901), Principes de Comptabilité des Sociétés par Actions à l'Usage des Administrateurs, Commissaires, Directeurs et Actionnaires de Sociétés (Ghent: Vandeweghe).

François, A. (1907), Inventaires et Bilans dans les Sociétés par Actions (Ghent: Vandeweghe).

Frank, M.Z. and V.K. Goyal (2003), 'Capital Structure Decisions', Working Paper (University of British Columbia).

Franks, J., C. Mayer and H.F. Wagner (2006), 'The Origins of the German Corporation - Finance, Ownership and Control', Review of Finance, Vol. 10, No. 4. 
Goodhart, C. and P. J. R. Delargy (1998), 'Financial Crises: Plus ça Change, Plus C'Est la Même Chose.' Working Paper (London School of Economics).

Huang, S.G.H. and F.M. Song (2002), 'The Determinants of Capital Structure: Evidence from China', Working Paper (The University of Hong Kong).

Jagannathan, M. and S. Krishnamurthy (2004), 'The Benefits of Investment Banker Directorships', Working Paper (Binghamton University).

Janssens, P., H. Verboven and A. Tiberghien (1990), Drie Eeuwen Belgische Belastingen. (Brussels: Fiscale Hogeschool).

Jensen, M.C. and W.H. Meckling (1976), 'Theory of the Firm: Managerial Behavior, Agency Costs, and Ownership Structure', Journal of Financial Economics, Vol. 3, pp. 305-360.

Jensen, M.C. (1986), 'Agency Costs of Free Cash Flow, Corporate Finance and Takeovers', American Economic Review, Vol. 76, pp. 323-329.

Korajczyk, R.A., D.J. Lucas and R.L. McDonald (1991), 'The Effect of Information Relaeses on the Pricing and Timing of Equity', Review of Financial Studies, Vol. 4, No. 4, pp. 685-708.

Krozner, R.S. and P.E. Strahan (2001), 'Bankers on Board: Monitoring, Conflicts of Interest, and Lender Liability', Journal of Financial Economics, Vol. 62, pp. 415-452.

Kurgan-Van Hentenryk, G. (1991), 'Finance and Financiers in Belgium, 1880-1914' in Y. Cassis (ed.), Finance and Financiers in European History, 1880-1960 (Cambridge University Press). 
Kurshev, A. and I.A. Strebulaev (2005), 'Firm Size and Capital Structure', Working Paper (London Business School).

Lucas, D.J. and R.L. McDonald (1990), 'Equity Issues and Stock Price Dynamics', Journal of Finance, Vol. 45, No. 4, pp. 1019-1043.

Modigliani, F., and M.H. Miller (1958), 'The Cost of Capital, Corporation Finance and the Theory of Investment.', American Economic Review, Vol. 48, pp. 261-297.

Musacchio, A. (2006), 'Can Civil Law Countries Get Good Institutions? Creditor Rights and Bond Markets in Brazil (and the World), 1850-2003', Working Paper (Harvard Business School).

Myers, S.C. and N.S. Majluf (1984), 'Corporate Financing and Investment Decisions when Firms Have Information that Investors Do Not Have', Journal of Financial Economics, Vol. 13, pp. 187-221.

Myers, S.C. (1977), 'Determinants of Corporate Borrowing', Journal of Financial Economics, Vol. 5, pp. 147-175.

Petersen, M.A. (2006), 'Estimating Standard Errors in Finance Panel Data Sets: Comparing Approaches', Working Paper (Northwestern University).

Rajan, R. (1992), 'Insiders and Outsiders: The Choice Between Informed and Arm's Length Debt', Journal of Finance, Vol. 47, No. 4, pp. 1367-1400.

Rajan, R.G. and L. Zingales. (1995), 'What Do We Know About Capital Structure? Some Evidence from International Data', Journal of Finance, Vol. 50, pp. 1421-1460. 
Rajan, R.G. and L. Zingales (2003), 'The Great Reversals: The Politics of Financial Development in the 20th Century', Journal of Financial Economics, Vol. 69, No. 1, pp. 5-50.

Ramirez, C.D. (1995), ‘Did J. P. Morgan’s Men Add Liquidity? Corporate Investment, Cash-Flow and Financial Structure at the Turn of the Twentieth Century.', Journal of Finance, Vol. 50, No. 2, pp.661-678.

Resteau, C. (1913a), Commentaire Législatif de la Loi du 25 mai 1913 Portant Modifications aux Lois sur les Sociétés Anonymes (Brussels : Imprimerie Veuve Ferdinand Larcier)

Resteau, C, (1913b), Les Sociétés Anonymes devant les Lois Belges (Brussels : Imprimerie Veuve Ferdinand Larcier)

Strebulaev, I.A. (2006), 'Do Tests of Capital Structure Theory Mean What They Say?', Journal of Finance, forthcoming.

Stultz, R.M. (1990), 'Managerial Discretion and Optimal Financing Policies', Journal of Financial Economics, Vol. 29, pp. 3-27.

Théate, T. (1905), Les Sociétés Anonymes: Abus et Remèdes (Paris: Mish \& Thron).

Titman, S. and R. Wessels (1988), 'The Determinants of Capital Structure Choice', Journal of Finance, Vol. 43, pp. 1-19.

Van Overfelt, W., J. Annaert, M. De Ceuster and M. Deloof (2006), 'Do Universal Banks Create Value? Universal Bank Affiliation and Company Performance in Belgium, 1905-1909’, Working Paper (University of Antwerp). 
Wautelet, J. M. (1976), 'Dynamique de l'Accumulation dans les Charbonnages Belges (1886-1914). Une approche par les bilans', Working Paper (CREHDIS).

Welch, I. (2004), 'Capital Structure and Stock Returns', Journal of Political Economy, Vol. 112, No. 1, pp. 106-131. 
Table 1

Number of observations for each industry

\begin{tabular}{c|cccc|c}
\hline & Coal-mining & Trams & Railways & Textile & Total \\
\hline 1905 & 68 & 13 & 7 & 13 & 101 \\
1906 & 69 & 17 & 7 & 13 & 106 \\
1907 & 73 & 17 & 8 & 20 & 118 \\
1908 & 70 & 19 & 7 & 20 & 116 \\
1909 & 73 & 18 & 7 & 17 & 115 \\
\hline
\end{tabular}




\section{Table 2}

\section{Descriptive Statistics}

This table reports descriptive statistics for a sample of 556 firm-year observations for 129 listed Belgian firms in the coal mining, trams, railways and textile industries in the period 1905-1909. The descriptives for Stock Return are based on 554 firm-year observations. The debt variables are scaled by the market value of equity plus the book value of total debt (Market) or by the book value of total assets (Book). The market-to-book ratio of equity (MTB) is market value of equity (aggregated over all categories of stock) divided by the book value of equity at the beginning of the fiscal year. Asset tangibility is the ratio of fixed assets over the book value of total assets at the beginning of the fiscal year. Profitability is operating profit plus depreciation over the fiscal year, divided by the book value of total assets at the beginning of the fiscal year. Ln(size) is the natural logarithm of total assets at the beginning of the fiscal year. Ln(age) is the natural logarithm of difference between the current year and the year the firm transformed to a limited liability company. Prior stock return is the stock return net of dividends over the previous fiscal year.

\begin{tabular}{cccccc}
\hline & Mean & Median & $\begin{array}{c}\text { Standard } \\
\text { Deviation }\end{array}$ & Minimum & Maximum \\
\hline Total Debt (Market) & 0.198 & 0.107 & 0.220 & 0.001 & 0.998 \\
Total Debt (Book) & 0.269 & 0.199 & 0.231 & 0.001 & 0.998 \\
Bonds (Market) & 0.103 & 0.000 & 0.162 & 0.000 & 0.841 \\
Bonds (Book) & 0.126 & 0.000 & 0.187 & 0.000 & 0.843 \\
Other Debt (Market) & 0.095 & 0.050 & 0.110 & 0.000 & 0.591 \\
Other Debt (Book) & 0.143 & 0.095 & 0.136 & 0.000 & 0.747 \\
Market-to-Book & 2.305 & 1.694 & 2.058 & 0.040 & 15.994 \\
Asset Tangibility & 0.453 & 0.499 & 0.290 & 0.000 & 0.963 \\
Profitability & 0.138 & 0.113 & 0.117 & -0.255 & 0.871 \\
Ln(Size) & 15.432 & 15.328 & 0.948 & 13.727 & 18.737 \\
Ln(Age) & 3.077 & 3.178 & 0.826 & 0.000 & 4.394 \\
Prior Stock Return & 0.096 & 0.028 & 0.288 & -0.590 & 2.191 \\
\hline
\end{tabular}




\section{Table 3}

\section{Mean and median values by industry}

This table reports mean and median values by industry for a sample of 556 firm-year observations for 129 listed Belgian firms in the coal mining, tram, railways and textile industries in the period 1905-1909. prior stock return is based on 83 observations in the trams industry and on 82 observations in the textile industry. The debt variables are scaled by the market value of equity plus the book value of total debt (Market) or by the book value of total assets (Book). The market-to-book ratio of equity (MTB) is market value of equity (aggregated over all categories of stock) divided by the book value of equity at the beginning of the fiscal year. Asset tangibility is the ratio of fixed assets over the book value of total assets at the beginning of the fiscal year. Profitability is operating profit plus depreciation over the fiscal year, divided by the book value of total assets at the beginning of the fiscal year. Ln(size) is the natural logarithm of total assets at the beginning of the fiscal year. Ln(age) is the natural logarithm of difference between the current year and the year the firm transformed to a limited liability company. Prior stock return is the stock return net of dividends over the previous fiscal year.

\begin{tabular}{c|cc|cc|cc|cc}
\hline & \multicolumn{2}{|c|}{ Coal-Mining } & \multicolumn{2}{c|}{ Trams } & \multicolumn{2}{c}{ Railways } & \multicolumn{2}{c}{ Textile } \\
& Mean & Median & Mean & Median & Mean & Median & Mean & Median \\
\hline Total Debt (Market) & 0.091 & 0.056 & 0.345 & 0.306 & 0.465 & 0.442 & 0.388 & 0.356 \\
Total Debt (Book) & 0.168 & 0.115 & 0.350 & 0.520 & 0.416 & 0.314 & 0.421 & 0.390 \\
Bonds (Market) & 0.033 & 0.000 & 0.242 & 0.000 & 0.379 & 0.423 & 0.137 & 0.133 \\
Bonds (Book) & 0.050 & 0.000 & 0.350 & 0.000 & 0.332 & 0.285 & 0.136 & 0.166 \\
Other Debt (Market) & 0.058 & 0.039 & 0.104 & 0.063 & 0.086 & 0.026 & 0.251 & 0.228 \\
Other Debt (Book) & 0.118 & 0.081 & 0.131 & 0.111 & 0.083 & 0.227 & 0.286 & 0.275 \\
Market-to-Book & 2.618 & 2.004 & 2.378 & 1.850 & 1.182 & 0.775 & 1.390 & 1.280 \\
Asset Tangibility & 0.470 & 0.515 & 0.436 & 0.557 & 0.503 & 0.641 & 0.380 & 0.384 \\
Profitability & 0.169 & 0.152 & 0.077 & 0.060 & 0.042 & 0.017 & 0.108 & 0.090 \\
Ln(Size) & 15.178 & 15.176 & 16.023 & 15.895 & 16.570 & 16.436 & 15.420 & 15.412 \\
Ln(Age) & 3.188 & 3.219 & 2.503 & 2.398 & 3.773 & 3.795 & 2.886 & 3.091 \\
Prior Stock Return & 0.139 & 0.072 & -0.003 & -0.030 & -0.004 & 0.000 & 0.054 & -0.009 \\
Firm-Year Observations & 353 & 353 & 84 & 84 & 36 & 36 & 83 & 83 \\
\hline
\end{tabular}




\section{Table 4}

\section{Bank Relationships}

For a sample of 129 listed Belgian firms in the coal mining, trams railways and textile industries, this table reports the distribution of firms according to the number of bank directors and the number of related banks. A firm is related to a bank if an executive director of the bank is a member of the executive board of the firm.

\begin{tabular}{c|llll|l}
\hline Number of Bank Directors & \multicolumn{4}{|l|}{ Number of Related Banks $\rightarrow$} \\
& 1 & 1 & 2 & 3 & Total \\
\hline 1 & 26 & & & 26 \\
2 & 5 & 2 & & 7 \\
3 & 3 & 5 & 0 & 8 \\
& 4 & 1 & 3 & 2 & 6 \\
\hline Total & 35 & 10 & 2 & 47
\end{tabular}




\section{Table 5}

\section{Factors Correlated with Leverage}

Regressions are based on a sample of 556 firm-year observations for 129 listed Belgian firms in the coal mining, trams, railways and textile industries in the period 1905-1909. The debt variables are scaled by the market value of equity plus the book value of total debt (Market) or by the book value of total assets (Book). The bonds dummy equals one if the firm had bonds outstanding, and zero otherwise. The market-to-book ratio of equity (MTB) is market value of equity (aggregated over all categories of stock) divided by the book value of equity at the beginning of the fiscal year. Asset tangibility is the ratio of fixed assets over the book value of total assets at the beginning of the fiscal year. Profitability is operating profit plus depreciation over the fiscal year, divided by the book value of total assets at the beginning of the fiscal year. $\mathrm{Ln}$ (size) is the natural logarithm of total assets at the beginning of the fiscal year. Ln(age) is the natural logarithm of difference between the current year and the year the firm transformed to a limited liability company. Bank director is a dummy which equals one if the firm had a director interlock with a universal bank, and zero otherwise. Coal-mining is a dummy which equals one if the firm is a coal-mining firm, and zero otherwise. Railways is a dummy which equals one if the firm is a railways firm, and zero otherwise. Trams is a dummy which equals one if the firm is a trams firm, and zero otherwise. All regressions include year dummies. Pvalues (robust for heteroscedasticity) are in parentheses below each coefficient. P-values for random effects estimations are based on clustered standard errors. ***: denotes significance at the $1 \%$ level; **: denotes significance at the $5 \%$ level; *: denotes significance at the $10 \%$ level.

\begin{tabular}{|c|c|c|c|c|c|c|c|}
\hline Regression & (1) & (2) & (3) & (4) & (5) & (6) & (7) \\
\hline Estimation Method & $\begin{array}{l}\text { Random } \\
\text { Effects }\end{array}$ & $\begin{array}{l}\text { Random } \\
\text { Effects }\end{array}$ & $\begin{array}{l}\text { Random } \\
\text { Probit }\end{array}$ & $\begin{array}{l}\text { Random } \\
\text { Effects }\end{array}$ & $\begin{array}{l}\text { Random } \\
\text { Effects }\end{array}$ & $\begin{array}{l}\text { Random } \\
\text { Effects }\end{array}$ & $\begin{array}{l}\text { Random } \\
\text { Effects }\end{array}$ \\
\hline $\begin{array}{l}\text { Dependent } \\
\text { Variable }\end{array}$ & $\begin{array}{c}\text { Total Debt } \\
\text { (Market) }\end{array}$ & $\begin{array}{c}\text { Total Debt } \\
\text { (Book) }\end{array}$ & $\begin{array}{l}\text { Bonds } \\
\text { Dummy }\end{array}$ & $\begin{array}{l}\text { Bonds } \\
\text { (Market) }\end{array}$ & $\begin{array}{l}\text { Bonds } \\
\text { (Book) }\end{array}$ & $\begin{array}{l}\text { Other Debt } \\
\text { (Market) }\end{array}$ & $\begin{array}{l}\text { Other } \\
\text { Debt } \\
\text { (Book) }\end{array}$ \\
\hline Market-to-Book & $\begin{array}{c}0.000 \\
(0.973)\end{array}$ & $\begin{array}{c}0.013 * * * \\
(0.004)\end{array}$ & $\begin{array}{l}-0.006 \\
(0.967)\end{array}$ & $\begin{array}{c}0.002 \\
(0.572)\end{array}$ & $\begin{array}{c}0.005 \\
(0.137)\end{array}$ & $\begin{array}{l}-0.003 \\
(0.143)\end{array}$ & $\begin{array}{l}0.011 * \\
(0.085)\end{array}$ \\
\hline Asset Tangibility & $\begin{array}{c}0.125 * * \\
(0.012)\end{array}$ & $\begin{array}{l}0.127 * \\
(0.069)\end{array}$ & $\begin{array}{c}3.316^{* * * *} \\
(0.000)\end{array}$ & $\begin{array}{c}0.160 * * * \\
(0.001)\end{array}$ & $\begin{array}{c}0.238 * * * \\
(0.000)\end{array}$ & $\begin{array}{l}-0.053 * \\
(0.079)\end{array}$ & $\begin{array}{c}-0.124 * * * \\
(0.000)\end{array}$ \\
\hline Profitability & $\begin{array}{c}-0.129 * * \\
(0.036)\end{array}$ & $\begin{array}{c}-0.253^{* * *} \\
(0.001)\end{array}$ & $\begin{array}{l}-2.334 \\
(0.210)\end{array}$ & $\begin{array}{l}-0.060 \\
(0.147)\end{array}$ & $\begin{array}{c}-0.145^{* *} \\
(0.022)\end{array}$ & $\begin{array}{c}-0.085^{* *} \\
(0.032)\end{array}$ & $\begin{array}{c}-0.120 * * \\
(0.044)\end{array}$ \\
\hline Ln(Size) & $\begin{array}{c}0.056^{* * * *} \\
(0.000)\end{array}$ & $\begin{array}{c}0.070 * * * \\
(0.001)\end{array}$ & $\begin{array}{c}1.023 * * * \\
(0.002)\end{array}$ & $\begin{array}{c}0.052 * * * \\
(0.000)\end{array}$ & $\begin{array}{c}0.060 * * * \\
(0.000)\end{array}$ & $\begin{array}{c}0.007 \\
(0.396)\end{array}$ & $\begin{array}{c}0.010 \\
(0.290)\end{array}$ \\
\hline Ln(Age) & $\begin{array}{c}0.041 * * \\
(0.024)\end{array}$ & $\begin{array}{c}0.047 * * * \\
(0.005)\end{array}$ & $\begin{array}{c}0.498 \\
(0.129)\end{array}$ & $\begin{array}{c}0.025 * * * \\
(0.004)\end{array}$ & $\begin{array}{c}0.026 * * \\
(0.011)\end{array}$ & $\begin{array}{c}0.012 \\
(0.244)\end{array}$ & $\begin{array}{l}0.019 * \\
(0.085)\end{array}$ \\
\hline Bank Director & $\begin{array}{c}-0.067 * * \\
(0.045)\end{array}$ & $\begin{array}{l}-0.019 \\
(0.611)\end{array}$ & $\begin{array}{l}-0.604 \\
(0.313)\end{array}$ & $\begin{array}{c}-0.059 * * \\
(0.012)\end{array}$ & $\begin{array}{l}-0.030 \\
(0.262)\end{array}$ & $\begin{array}{l}-0.007 \\
(0.707)\end{array}$ & $\begin{array}{c}0.009 \\
(0.675)\end{array}$ \\
\hline Railways & $\begin{array}{l}-0.048 \\
(0.659)\end{array}$ & $\begin{array}{l}-0.173 \\
(0.114)\end{array}$ & $\begin{array}{l}-0.485 \\
(0.724)\end{array}$ & $\begin{array}{l}0.140 * \\
(0.083)\end{array}$ & $\begin{array}{c}0.064 \\
(0.419)\end{array}$ & $\begin{array}{c}-0.187 * * * \\
(0.001)\end{array}$ & $\begin{array}{c}-0.233 * * * \\
(0.000)\end{array}$ \\
\hline Trams & $\begin{array}{l}-0.068 \\
(0.265)\end{array}$ & $\begin{array}{l}-0.010 \\
(0.863)\end{array}$ & $\begin{array}{c}1.243 \\
(0.227)\end{array}$ & $\begin{array}{c}0.070 \\
(0.105)\end{array}$ & $\begin{array}{c}0.154 * * * \\
(0.001)\end{array}$ & $\begin{array}{c}-0.141 * * * \\
(0.000)\end{array}$ & $\begin{array}{c}-0.166 * * * \\
(0.000)\end{array}$ \\
\hline Coal-Mining & $\begin{array}{c}-0.292 * * * \\
(0.000)\end{array}$ & $\begin{array}{c}-0.270 * * * \\
(0.000)\end{array}$ & $\begin{array}{c}-2.384 * * * \\
(0.001)\end{array}$ & $\begin{array}{c}-0.112 * * * \\
(0.000)\end{array}$ & $\begin{array}{c}-0.103^{* * *} \\
(0.000)\end{array}$ & $\begin{array}{c}-0.174 * * * \\
(0.000)\end{array}$ & $\begin{array}{c}-0.168 * * * \\
(0.000)\end{array}$ \\
\hline Constant & $\begin{array}{c}-0.608 * * \\
(0.012)\end{array}$ & $\begin{array}{c}-0.819 * * * \\
(0.009)\end{array}$ & $\begin{array}{c}-16.928 * * * \\
(0.001)\end{array}$ & $\begin{array}{c}-0.778 * * * \\
(0.000)\end{array}$ & $\begin{array}{c}-0.930 * * * \\
(0.000)\end{array}$ & $\begin{array}{l}-0.138 \\
(0.302)\end{array}$ & $\begin{array}{c}0.120 * * * \\
(0.414)\end{array}$ \\
\hline $\mathrm{R}^{2}$ & 0.479 & 0.424 & & 0.508 & 0.488 & 0.453 & 0.430 \\
\hline
\end{tabular}




\section{Table 6}

\section{Factors Correlated with Leverage - Bank Relationships}

Regressions are based on a sample of 556 firm-year observations for 129 listed Belgian firms in the coal mining, trams, railways and textile industries in the period 1905-1909. The debt variables are scaled by the market value of equity plus the book value of total debt (Market) or by the book value of total assets (Book). The marketto-book ratio of equity (MTB) is market value of equity (aggregated over all categories of stock) divided by the book value of equity at the beginning of the fiscal year. Asset tangibility is the ratio of fixed assets over the book value of total assets at the beginning of the fiscal year. Profitability is operating profit plus depreciation over the fiscal year, divided by the book value of total assets at the beginning of the fiscal year. $\operatorname{Ln}($ size) is the natural logarithm of total assets at the beginning of the fiscal year. Ln(age) is the natural logarithm of difference between the current year and the year the firm transformed to a limited liability company. Bank director is a dummy which equals one if the firm had a director interlock with a universal bank, and zero otherwise. Number of bank directors is the number of director interlocks with a universal bank. Number of related banks is the number of banks of which a director was a director on the board of the firm. All regressions include year dummies and industry dummies. P-values (robust for heteroscedasticity) are in parentheses below each coefficient. P-values for random effects estimations are based on clustered standard errors. $* * *$ : denotes significance at the $1 \%$ level; $* *$ : denotes significance at the $5 \%$ level; *: denotes significance at the $10 \%$ level.

\begin{tabular}{|c|c|c|c|c|}
\hline Regression & (8) & (9) & $(10)$ & $(11)$ \\
\hline Estimation method & $\begin{array}{l}\text { Random } \\
\text { Effects }\end{array}$ & $\begin{array}{l}\text { Random } \\
\text { Effects }\end{array}$ & $\begin{array}{l}\text { Random } \\
\text { Effects }\end{array}$ & $\begin{array}{l}\text { Random } \\
\text { Effects }\end{array}$ \\
\hline Dependent Variable & $\begin{array}{l}\text { Total Debt } \\
\text { (Market) }\end{array}$ & $\begin{array}{l}\text { Total Debt } \\
\text { (Book) }\end{array}$ & $\begin{array}{l}\text { Total Debt } \\
\text { (Market) }\end{array}$ & $\begin{array}{l}\text { Total Debt } \\
\text { (Book) }\end{array}$ \\
\hline Market-to-Book & $\begin{array}{c}0.000 \\
(0.898)\end{array}$ & $\begin{array}{c}0.013 * * * \\
(0.007)\end{array}$ & $\begin{array}{c}0.000 \\
(0.934)\end{array}$ & $\begin{array}{c}0.012 * * * \\
(0.006)\end{array}$ \\
\hline Asset Tangibility & $\begin{array}{c}0.126 * * \\
(0.013)\end{array}$ & $\begin{array}{l}0.127 * \\
(0.069)\end{array}$ & $\begin{array}{c}0.125 * * \\
(0.013)\end{array}$ & $\begin{array}{l}0.128 * \\
(0.068)\end{array}$ \\
\hline Profitability & $\begin{array}{c}-0.129 * * \\
(0.036)\end{array}$ & $\begin{array}{c}-0.253 * * * \\
(0.001)\end{array}$ & $\begin{array}{c}-0.129 * * \\
(0.036)\end{array}$ & $\begin{array}{c}-0.253 * * * \\
(0.001)\end{array}$ \\
\hline Ln(Size) & $\begin{array}{c}0.058 * * * \\
(0.000)\end{array}$ & $\begin{array}{c}0.069 * * * \\
(0.001)\end{array}$ & $\begin{array}{c}0.057 * * * \\
(0.000)\end{array}$ & $\begin{array}{c}0.068 * * * \\
(0.001)\end{array}$ \\
\hline Ln(Age) & $\begin{array}{c}0.043 * * \\
(0.023)\end{array}$ & $\begin{array}{c}0.046^{* * *} \\
(0.006)\end{array}$ & $\begin{array}{c}0.042 * * \\
(0.024)\end{array}$ & $\begin{array}{c}0.046 * * * \\
(0.006)\end{array}$ \\
\hline Bank Director & $\begin{array}{l}-0.034 \\
(0.541)\end{array}$ & $\begin{array}{l}-0.030 \\
(0.621)\end{array}$ & $\begin{array}{l}-0.039 \\
(0.505)\end{array}$ & $\begin{array}{l}-0.071 \\
(0.286)\end{array}$ \\
\hline Number of Bank Directors & $\begin{array}{l}-0.018 \\
(0.311)\end{array}$ & $\begin{array}{c}0.006 \\
(0.810)\end{array}$ & & \\
\hline Number of Related Banks & & & $\begin{array}{l}-0.022 \\
(0.452)\end{array}$ & $\begin{array}{c}0.041 \\
(0.325)\end{array}$ \\
\hline Industry dummies & Included & Included & Included & Included \\
\hline $\mathrm{R}^{2}$ & 0.482 & 0.424 & 0.481 & 0.426 \\
\hline
\end{tabular}




\section{Table 7}

\section{Factors Correlated with Leverage -Prior Stock Return}

Regressions are based on a sample of 554 firm-year observations for 129 listed Belgian firms in the coal mining, trams, railways and textile industries in the period 1905-1909. The debt variables are scaled by the market value of equity plus the book value of total debt (Market) or by the book value of total assets (Book). The market-to-book ratio of equity (MTB) is market value of equity (aggregated over all categories of stock) divided by the book value of equity at the beginning of the fiscal year. Asset tangibility is the ratio of fixed assets over the book value of total assets at the beginning of the fiscal year. Profitability is operating profit plus depreciation over the fiscal year, divided by the book value of total assets at the beginning of the fiscal year. $\operatorname{Ln}(\operatorname{size})$ is the natural logarithm of total assets at the beginning of the fiscal year. Ln(age) is the natural logarithm of difference between the current year and the year the firm transformed to a limited liability company. Bank director is a dummy which equals one if the firm had a director interlock with a universal bank, and zero otherwise. Prior stock return is the stock return net of dividends over the previous fiscal year. All regressions include year dummies and industry dummies. P-values (robust for heteroscedasticity) are in parentheses below each coefficient. P-values for random effects estimations are based on clustered standard errors. $* * *$ : denotes significance at the $1 \%$ level; $* *$ : denotes significance at the $5 \%$ level; *: denotes significance at the $10 \%$ level.

\begin{tabular}{ccccc}
\hline Regression & $(12)$ & $(13)$ & $(14)$ & $(15)$ \\
Estimation method & $\begin{array}{c}\text { Random } \\
\text { Effects }\end{array}$ & $\begin{array}{c}\text { Random } \\
\text { Effects }\end{array}$ & $\begin{array}{c}\text { Random } \\
\text { Effects }\end{array}$ & $\begin{array}{c}\text { Random } \\
\text { Effects }\end{array}$ \\
Dependent Variable & $\begin{array}{c}\text { Total Debt } \\
\text { (Market) }\end{array}$ & $\begin{array}{c}\text { Total Debt } \\
\text { (Book) }\end{array}$ & $\begin{array}{c}\text { Bonds } \\
\text { (Market) }\end{array}$ & $\begin{array}{c}\text { Other Debt } \\
\text { (Market) }\end{array}$ \\
\hline Market-to-Book & -0.005 & $0.013 * * *$ & -0.001 & $-0.005 * *$ \\
& $(0.387)$ & $(0.007)$ & $(0.869)$ & $(0.028)$ \\
Asset Tangibility & $0.131 * *$ & $0.124 *$ & $0.163 * * *$ & $-0.054 *$ \\
& $(0.012)$ & $(0.076)$ & $(0.001)$ & $(0.073)$ \\
Profitability & -0.078 & $-0.255^{* * *}$ & -0.035 & $-0.061 *$ \\
Ln(Size) & $(0.182)$ & $(0.001)$ & $(0.433)$ & $(0.094)$ \\
& $0.057 * * *$ & $0.071 * * *$ & $0.053 * * *$ & 0.007 \\
Ln(Age) & $(0.000)$ & $(0.000)$ & $(0.000)$ & $(0.386)$ \\
& $0.047 * *$ & $0.045 * * *$ & $0.028 * * *$ & 0.013 \\
R ${ }^{2}$ & $(0.014)$ & $(0.008)$ & $(0.002)$ & $(0.198)$ \\
Bndustry Dummies & Included & Included & Included & Included \\
Prior Stock Return & 0.476 & 0.425 & 0.508 & 0.450 \\
\hline & $-0.065 *$ & -0.020 & $-0.058^{* *}$ & -0.005 \\
& $(0.057)$ & $(0.603)$ & $(0.016)$ & $(0.765)$ \\
& & 0.005 & $-0.029 *$ & $-0.028 * * *$ \\
& $(0.007)$ & $(0.716)$ & $(0.072)$ & $(0.001)$ \\
& & &
\end{tabular}




\section{Appendix}

\section{Firms included in the sample}

This table gives an overview of all the firms included in the sample, their average year-end market value of equity (expressed in Belgian Francs) and the industry to which they belong.

\begin{tabular}{|c|c|c|}
\hline Firm & $\begin{array}{c}\text { Average Market Value } \\
\text { of Equity (BEF) }\end{array}$ & Industry \\
\hline Charbonnages de Gives & 948.750 & Coal-Mining \\
\hline Charbonnage d'amercoeur & 25.480 .000 & Coal-Mining \\
\hline Charbonnage de Bascoup & 53.366 .667 & Coal-Mining \\
\hline Charbonnage de bonne fin & 10.499 .000 & Coal-Mining \\
\hline Charbonnage de Bonne-Esperance et Batterie & 11.260 .000 & Coal-Mining \\
\hline Charbonnage de falnuee & 714.267 & Coal-Mining \\
\hline Charbonnage de fontaine l'eveque & 17.900 .000 & Coal-Mining \\
\hline Charbonnage de Forte Taille & 1.287 .600 & Coal-Mining \\
\hline Charbonnage de gosson lagasse & 10.878 .000 & Coal-Mining \\
\hline Charbonnage de Ham-sur-Sambre et Moustier & 9.730 .000 & Coal-Mining \\
\hline Charbonnage de herve-wergifosse & 2.412 .400 & Coal-Mining \\
\hline Charbonnage de Kessales & 15.380 .000 & Coal-Mining \\
\hline Charbonnage de la grande bacnure & 9.817 .376 & Coal-Mining \\
\hline Charbonnage de la grande machine a feu de dour & 9.661 .000 & Coal-Mining \\
\hline Charbonnage de la Haye & 15.580 .000 & Coal-Mining \\
\hline Charbonnage de l'Arbre St Michel & 1.854 .000 & Coal-Mining \\
\hline Charbonnage de l'esperance et bonne fortune & 18.340 .000 & Coal-Mining \\
\hline Charbonnage de Lonette & 619.600 & Coal-Mining \\
\hline Charbonnage de Marchienne & 3.893 .750 & Coal-Mining \\
\hline Charbonnage de Marcinelle-Nord & 9.700 .000 & Coal-Mining \\
\hline Charbonnage de Mariemont & 11.509 .280 & Coal-Mining \\
\hline Charbonnage de Maurage & 2.478 .750 & Coal-Mining \\
\hline Charbonnage de noel sart culpart & 13.304 .000 & Coal-Mining \\
\hline Charbonnage de Wérister & 15.820 .000 & Coal-Mining \\
\hline Charbonnage du bois d'avroy & 12.460 .000 & Coal-Mining \\
\hline Charbonnage du Borinage Central & 1.108 .000 & Coal-Mining \\
\hline Charbonnage du carabinier & 2.812 .000 & Coal-Mining \\
\hline Charbonnage du Corbeau au Berleur & 1.600 .529 & Coal-Mining \\
\hline Charbonnage du Gouffre & 7.727 .050 & Coal-Mining \\
\hline Charbonnage du Grand-Mambourg Sablonniere & 5.020 .800 & Coal-Mining \\
\hline Charbonnage du Hasard & 9.310 .000 & Coal-Mining \\
\hline Charbonnage du monceau fontaine et du martinet & 35.380 .000 & Coal-Mining \\
\hline Charbonnage du Nord de Genly a Frameries & 893.750 & Coal-Mining \\
\hline Charbonnage du nord du charleroi & 21.325 .000 & Coal-Mining \\
\hline Charbonnage reunis de la concorde & 6.382 .500 & Coal-Mining \\
\hline Charbonnages belges & 13.380 .419 & Coal-Mining \\
\hline Charbonnages couchant du flénu & 5.308 .690 & Coal-Mining \\
\hline Charbonnages d'Abhooz et Bonne-Foi-Hareng & 8.592 .500 & Coal-Mining \\
\hline Charbonnages d'Aiseau-Presles & 5.060 .160 & Coal-Mining \\
\hline Charbonnages d'Ans et de Rocour & 2.458 .750 & Coal-Mining \\
\hline Charbonnages de Bernissart & 8.600 .136 & Coal-Mining \\
\hline Charbonnages de Bonne-Esperance & 2.862 .963 & Coal-Mining \\
\hline Charbonnages de Centre de Jumet & 5.709 .000 & Coal-Mining \\
\hline Charbonnages de courcelles nord & 22.340 .000 & Coal-Mining \\
\hline Charbonnages de Falisolle & 8.652 .400 & Coal-Mining \\
\hline
\end{tabular}


Charbonnages de grand conti et spinois

Charbonnages de Hornu et Wasmes

Charbonnages de La Louviere et Sars-Longchamps et Bouvy

Charbonnages de la Petite Bacnure

Charbonnages de l'Est de Liege

Charbonnages de Masses-diarbois

Charbonnages de Monceau-Bayemont et Chauw a Roc

Charbonnages de Patience et Beaujonc Reunis

Charbonnages de sacre-madame

Charbonnages de Tamines

Charbonnages des produits au flénu

Charbonnages des Quatre Jean

Charbonnages d'Ormont

Charbonnages du Horloz

Charbonnages du Nord de Flenu

Charbonnages du Nord de Gilly

Charbonnages du Nord du Rieu-du-coeur

Charbonnages du Petit-Try a Lambusart

Charbonnages du Poirier

Charbonnages du Rieu du Coeur et de la Boule reunis

Charbonnages du Trieu-Kaisin

Charbonnages et usines a coke Ressaix, Leval et St Aldegonde

Charbonnages levant du flénu

Charbonnages réunies a charleroi

Charbonnages Reunis de la Minerie

Charbonnages reunis de l'ouest de Mons

Chevalieres de dour

Grand-Bouillon et des Chevalieres du Bois de St.Ghislain a Dour

Houillerers unies du bassin de Charleroi

Houilleres d'Anderlues

Mines de Houille du Grand-Buisson

Strepy Bracquegnies

Chemin de fer Electrique d'Ostende-Blankenberghe et Extensions

Chemin de Fer Vicinal d'Ans a Oreye et extensions

Chemins de Fer Provinciaux

Compagnie Generale de Railways et d'Electricite

Compagnie Generale des Chemins de Fer Secondaires

Compagnie Generale des Tramways d'Anvers

Compagnie Mutuelle de Tramways

Federation Francaise et Belge de Tramways

Railways economiques de Liege, Seraing et extensions

Societe Generale des Chemins de Fer Economiques

Tram-car Nord-Midi

Tramways bruxellois

Tramways Electriques de Gand

Tramways electriques du pays de Charleroi et Extensions

Tramways Est-Ouest de Liege et Extensions

Tramways Liegeois

Tramways vervietois

Trust Franco-Belge de Tramways et d'Electricite

Union Anversoise de Tramways et Entreprises Electriques

Chemin de Fer de Maeseyck

Chemin de Fer de Mons a Haumont et de St.Ghislain

Chemin de Fer Jonction Belge Prusienne, dit Welkenraedt
2.788 .600

32.320 .000

9.693 .500

1.577 .831

3.267 .000

5.503 .200

6.678 .000

15.600 .000

12.640 .000

6.447 .200

23.120 .000

1.752 .800

3.029 .664

34.420 .000

3.525 .333

2.323 .700

4.748 .100

11.820 .000

2.665 .600

3.017 .933

18.140 .000

31.260 .000

24.725 .000

28.480 .000

1.554 .432

18.900 .000

7.315 .200

2.701 .995

11.044 .000

20.780 .000

5.481 .724

23.600 .000

7.056 .250

2.883 .000

1.859 .167

43.275 .000

31.220 .000

37.560 .000

5.308 .000

10.736 .500

6.891 .200

59.940 .000

1.279 .400

95.440 .000

4.221 .000

5.189 .779

4.988 .160

3.997 .275

5.225 .300

2.026 .500

7.584 .375

2.140 .600

23.233 .333

6.733 .250
Coal-Mining

Coal-Mining

Coal-Mining

Coal-Mining

Coal-Mining

Coal-Mining

Coal-Mining

Coal-Mining

Coal-Mining

Coal-Mining

Coal-Mining

Coal-Mining

Coal-Mining

Coal-Mining

Coal-Mining

Coal-Mining

Coal-Mining

Coal-Mining

Coal-Mining

Coal-Mining

Coal-Mining

Coal-Mining

Coal-Mining

Coal-Mining

Coal-Mining

Coal-Mining

Coal-Mining

Coal-Mining

Coal-Mining

Coal-Mining

Coal-Mining

Coal-Mining

Trams

Trams

Trams

Trams

Trams

Trams

Trams

Trams

Trams

Trams

Trams

Trams

Trams

Trams

Trams

Trams

Trams

Trams

Trams

Railways

Railways

Railways 
Chemins de fer de la flandre occidentale

29.100 .000

Railways

Chemins de fer de namur a liège et de mons a manage

Compagnie du Chemins de Fer de Braine Le Comte a Gand et ses extensions

$\begin{array}{cc}35.880 .000 & \text { Railways } \\ 1.356 .141 & \text { Railways } \\ 89.870 & \text { Railways } \\ 2.596 .667 & \text { Railways } \\ 5.173 .500 & \text { Textile } \\ 1.210 .667 & \text { Textile } \\ 5.192 .000 & \text { Textile } \\ 8.288 .000 & \text { Textile } \\ 2.333 .100 & \text { Textile } \\ 11.048 .000 & \text { Textile } \\ 5.689 .000 & \text { Textile } \\ 2.448 .000 & \text { Textile } \\ 1.860 .000 & \text { Textile } \\ 1.011 .583 & \text { Textile } \\ 1.967 .000 & \text { Textile } \\ 2.485 .000 & \text { Textile } \\ 2.390 .000 & \text { Textile } \\ 1.206 .900 & \text { Textile } \\ 1.770 .000 & \text { Textile } \\ 4.510 .000 & \text { Textile } \\ 15.720 .000 & \text { Textile } \\ 1.617 .000 & \text { Textile } \\ 3.532 .000 & \text { Textile }\end{array}$

Compagnie du Chemins de Fer de Gand a Terneuzen

Société anonyme du Chemin de Fer de Chimay

Société anonyme du Chemin de Fer de Termonde a St.Nicolas

Anciens Etablissements Morel et Verbeke

Compagnie industrielle du Levant

Cottoniere nouvelle Orleans

Etablissements Americains Gratry, a Courtrai

Fabrique Belge de matieres premieres pour la Chapellerie

Fabrique de Soie Artificielle de Tubize

Fabrique de Tresses et Lacets Torley

Filature de Roygem

Filature du Nord

Filature et Blanchisserie Reunies "La Ninovite"

Filature et Teinturerie d'Alost

La lainière peignage et filature de laine

La No

Liniere de St-Leonard

Liniere des Flandres

Liniere des Flandres

Linière gantoise

Loth pour la filature et la fabr de tissus de laines peignees

Peignage et filature de laine la vesdre

3.532 .000

Textile

Société Belge-Américane de la Preparation des Matieres premières pour la Chapellerie

1.534.800 Textile

5.574.375 Textile

Societe Cotonniere de St Etienne du Rouvray

16.320 .000

Textile

Société de la lys

3.765 .000

Textile

Stalle pour le blanchiment et l'impression des tissus

1.746 .667

Textile 